"The impact of family involvement in business on capital structure decisions: a literature review"

\begin{tabular}{|c|c|}
\hline AUTHORS & $\begin{array}{l}\text { Amr Ahmed Moussa (D https://orcid.org/0000-0002-2327-8895 } \\
\text { Khairy Elgiziry }\end{array}$ \\
\hline ARTICLE INFO & $\begin{array}{l}\text { Amr Ahmed Moussa and Khairy Elgiziry (2019). The impact of family involvement } \\
\text { in business on capital structure decisions: a literature review. Investment } \\
\text { Management and Financial Innovations, 16(1), 258-266. } \\
\text { doi:10.21511/imfi.16(1).2019.20 }\end{array}$ \\
\hline DOI & http://dx.doi.org/10.21511/imfi.16(1).2019.20 \\
\hline RELEASED ON & Tuesday, 19 March 2019 \\
\hline RECEIVED ON & Tuesday, 01 January 2019 \\
\hline ACCEPTED ON & Wednesday, 06 March 2019 \\
\hline LICENSE & $\begin{array}{l}(c) E Y \text { EY } \\
\text { This work is licensed under a Creative Commons Attribution } 4.0 \text { International } \\
\text { License }\end{array}$ \\
\hline JOURNAL & "Investment Management and Financial Innovations" \\
\hline ISSN PRINT & $1810-4967$ \\
\hline ISSN ONLINE & $1812-9358$ \\
\hline PUBLISHER & LLC "Consulting Publishing Company "Business Perspectives" \\
\hline FOUNDER & LLC "Consulting Publishing Company "Business Perspectives" \\
\hline
\end{tabular}

NUMBER OF REFERENCES

55
NUMBER OF FIGURES

0
NUMBER OF TABLES

1

(C) The author(s) 2022. This publication is an open access article. 


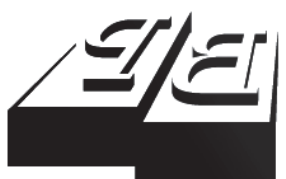

BUSINESS PERSPECTIVES

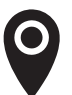

LLC "CPC "Business Perspectives" Hryhorii Skovoroda lane, 10, Sumy, 40022, Ukraine

www.businessperspectives.org

Received on: $1^{\text {st }}$ of January, 2019 Accepted on: $6^{\text {th }}$ of March, 2019

(C) Amr Ahmed Moussa, Khairy Elgiziry, 2019

Amr Ahmed Moussa, Assistant Lecturer, Department of Business Administration, Faculty of Commerce, Cairo University, Egypt.

Khairy Elgiziry, Professor of Finance, Department of Business Administration, Faculty of Commerce, Cairo University, Egypt.

\section{(ㄷ) (i)}

This is an Open Access article, distributed under the terms of the Creative Commons Attribution 4.0 International license, which permits unrestricted re-use, distribution, and reproduction in any medium, provided the original work is properly cited.

\title{
THE IMPACT OF FAMILY INVOLVEMENT IN BUSINESS ON CAPITAL STRUCTURE DECISIONS: A LITERATURE REVIEW
}

\begin{abstract}
Family-controlled firms are a unique form of business because of the special nature of its ownership structure, management style, and financing needs. Moreover, these firms face difficulty in achieving a balanced mix of available financing alternatives (i.e., debt and equity), and this mix has a direct impact on the firms' profitability, risk, and value. Therefore, the purpose of this study is to review the literature on how family involvement in business via ownership, management, and control affects capital structure decisions. The review showed that in a comparison with nonfamily businesses, familycontrolled firms on average have higher debt levels. Additionally, family ownership is positively associated with debt financing, and the participation of family members in a firm's top management leads to an increase in the firm's overall debt level. Insights generated from the current study highlight the critical influence of family involvement in business on key financial policies such as capital structure decisions.
\end{abstract}

Keywords corporate governance, capital structure, family firms
G30, G32, G34

\section{INTRODUCTION}

Family-controlled firms (FCFs) are the most predominant form of business around the world. It is estimated that $90 \%$ of privately held businesses in both North America (Canada and the United States) and the Middle East are FCFs. In the Middle East and North Africa, they contribute to nearly $80 \%$ of the region's GDP and employ about $70 \%$ of the national labor force (Global Family Business Center of Excellence, 2014). Furthermore, FCFs play a vital role in society and have many advantages, such as long-term planning, business stability, and encouraging an atmosphere of commitment through family trust, altruism, and paternalism (Mishra et al., 2001). Nevertheless, FCFs face many challenges and drawbacks. For instance, founders and their families, as controlling shareholders, may have the desire and ability to achieve their personal goals to the detriment of other shareholders, leading to the wealth expropriation of minority shareholders (Setia-Atmaja et al., 2009).

The financial literature has addressed three main conflicts of interest in corporate governance: (a) owners versus managers, (b) controlling versus noncontrolling owners, and (c) owners versus creditors. A fourth conflict, family owners versus family outsiders, is found only in FCFs (Villalonga et al., 2015). In family businesses, the degree of family involvement in the business affects the relationship between owners (i.e., founders and their families) and other stakeholders (e.g., managers, debt holders, and minority shareholders). Therefore, the percentage of 
equity shares held by a family and the involvement of founders and their family members in firms' top management and control are key drivers of firm performance and financial flexibility. Prior studies have found that FCFs show higher performance rates than their nonfamily counterparts (Anderson \& Reeb, 2003). However, an alternative view in the literature has reported a negative and endogenous influence of family involvement on business outcomes (Sciascia \& Mazzola, 2008).

These contrasting results might be explained by the absence of a standard and unanimous definition of family business, variations in legal and institutional settings across countries, and the degree of family participation in the business itself. For instance, firms that are $100 \%$ owned and managed by the founding family tend to have more goal congruence and less conflict. Thus, these companies are more likely to attain higher performance rates compared with businesses with different structures of ownership concentration (Che \& Langli, 2015). Similarly, family involvement in business affects different aspects of corporate financial policy such as capital structure decisions, corporate cash holdings, and payout policies, hence influencing firms' financial flexibility (e.g., Anderson et al., 2003; Kusnadi \& Wei, 2011; Vandemaele \& Vancauteren, 2015).

The main purpose of this study concerns the question: Does family involvement in business affects capital structure decisions? And to answer this question we reviewed the prior literature on capital structure within the context of FCFs. The researchers relied on the review of available quantitative-based studies retrieved from both EBSCO and ProQuest databases during the period from 2000 to 2018, with the exclusion of all studies related to nonfamily businesses, and small- and medium-sized firms (SMEs). Based on the review, we concluded that FCFs on average hold higher debt levels compared with nonfamily businesses and the participation of family members in top management leads to an increase in firm debt levels.

This study is expected to contribute to the financial knowledge and literature by, first, previous studies that have attempted to explain the relationship between family involvement in business and capital structure decisions from a single perspective (i.e., agency, stewardship and capital structure theories). Thus, the current study tried to fill this gap by providing a more comprehensive view, rather than using one of these perspectives as a single theoretical basis. Second, the current study explores the impact of family influence on capital structure decisions through different proxies as the degree of family involvement in ownership, management, and control, whereas the majority of the prior studies have focused on using these proxies separately. Finally, the study recommends a range of proposed visions that can contribute to the family businesses literature. The remainder of this paper is organized as follows: section one contains a review of prior studies related to the impact of family involvement in business on capital structure decisions. Section two presents the discussion, and finally, the last section presents the conclusion and offers directions for future research.

\section{LITERATURE REVIEW}

From the viewpoint of agency, stewardship and capital structure theories, a strand in the literature investigates the impact of family involvement in business on capital structure decisions. Table 1 shows that prior studies used many different measurements of capital structure decisions, including debt ratio ${ }^{1}$, book and market value of debt, debt maturity, debt variations, and cost of debt financing. The studies used family ownership, management, control, and succession to proxy family influence on capital structure decisions. Table 1 also shows the dominance of panel data methodology as an applied statistical tool in prior studies. The researchers of these studies used various panel data techniques, such as the generalized method of moments (GMM), generalized least squares (GLS), and ordinary least squares (OLS) with both fixed effects and random effects estimates to test the validity of their research hypotheses.

1 Debt ratio in most previous studies were measured by debt (i.e., book value of total debt) to total asset ratio. 
Table 1. Capital structure decisions in family firms literature by focus

Source: Author's own.

\begin{tabular}{|c|c|c|c|c|c|c|c|}
\hline Study & Sample & Country & $\begin{array}{c}\text { Theory/ } \\
\text { perspective }\end{array}$ & Methodology & $\begin{array}{l}\text { Dependent } \\
\text { variable/s }\end{array}$ & $\begin{array}{c}\text { Family } \\
\text { involvement } \\
\text { proxy }\end{array}$ & $\begin{array}{c}\text { Impact } \\
\text { of family } \\
\text { involvement }\end{array}$ \\
\hline $\begin{array}{l}\text { Acedo-Ramirez } \\
\text { et al. (2017) }\end{array}$ & $\begin{array}{l}2,093 \\
\text { unlisted } \\
\text { firms }\end{array}$ & Spain & $\begin{array}{c}\text { Agency and } \\
\text { capital structure } \\
\text { theories }\end{array}$ & Panel data: GMM & $\begin{array}{l}\text { Debt to total } \\
\text { assets ratio }\end{array}$ & $\begin{array}{l}\text { Family ownership } \\
\text { and management }\end{array}$ & Positive \\
\hline $\begin{array}{l}\text { Amore et al. } \\
(2011)\end{array}$ & $\begin{array}{l}2,484 \\
\text { unlisted } \\
\text { firms }\end{array}$ & Italy & Agency theory & $\begin{array}{l}\text { Panel data: OLS } \\
\text { with fixed effects }\end{array}$ & $\begin{array}{c}\text { Debt to capital } \\
\text { ratio }\end{array}$ & $\begin{array}{c}\text { Professional/family } \\
\text { succession }\end{array}$ & Negative \\
\hline $\begin{array}{l}\text { Ampenberger et } \\
\text { al. (2013) }\end{array}$ & $\begin{array}{l}660 \text { listed } \\
\text { firms }\end{array}$ & Germany & Agency theory & $\begin{array}{l}\text { Panel data: OLS } \\
\text { with fixed effects }\end{array}$ & $\begin{array}{l}\text { Long-term market } \\
\text { leverage }\end{array}$ & $\begin{array}{l}\text { Family ownership } \\
\text { and management }\end{array}$ & Negative \\
\hline $\begin{array}{l}\text { Anderson and } \\
\text { Reeb (2003) }\end{array}$ & $\begin{array}{l}252 \text { listed } \\
\text { firms }\end{array}$ & USA & $\begin{array}{l}\text { Agency and } \\
\text { stewardship } \\
\text { theories }\end{array}$ & $\begin{array}{l}\text { Panel data: OLS } \\
\text { with fixed effects }\end{array}$ & $\begin{array}{l}\text { Debt to total } \\
\text { assets ratio }\end{array}$ & $\begin{array}{l}\text { Family ownership } \\
\text { and management }\end{array}$ & Neutral \\
\hline $\begin{array}{l}\text { Anderson et al. } \\
(2003)\end{array}$ & $\begin{array}{l}319 \text { listed } \\
\text { firms }\end{array}$ & USA & Agency theory & OLS & Cost of debt & $\begin{array}{l}\text { Family ownership } \\
\text { and management }\end{array}$ & Positive \\
\hline $\begin{array}{l}\text { Baek et al. } \\
(2016)\end{array}$ & $\begin{array}{l}200 \text { listed } \\
\text { firms }\end{array}$ & USA & $\begin{array}{c}\text { Socioemotional } \\
\text { wealth }\end{array}$ & $\begin{array}{c}\text { Panel data: OLS } \\
\text { with random } \\
\text { effects }\end{array}$ & $\begin{array}{l}\text { Book and market } \\
\text { value of debt }\end{array}$ & $\begin{array}{l}\text { Family ownership } \\
\text { and management }\end{array}$ & Positive \\
\hline $\begin{array}{l}\text { Croci et al. } \\
(2011)\end{array}$ & $\begin{array}{l}777 \text { listed } \\
\text { firms }\end{array}$ & $\begin{array}{l}12 \text { Western } \\
\text { European } \\
\text { countries }\end{array}$ & $\begin{array}{c}\text { Agency and } \\
\text { capital structure } \\
\text { theories }\end{array}$ & $\begin{array}{l}\text { Panel data: OLS } \\
\text { with fixed effects }\end{array}$ & Debt variation & $\begin{array}{l}\text { Family ownership } \\
\text { and management }\end{array}$ & Positive \\
\hline $\begin{array}{l}\text { Díaz-Díaz et al. } \\
\text { (2016) }\end{array}$ & $\begin{array}{l}4,365 \\
\text { unlisted } \\
\text { firms }\end{array}$ & Spain & Agency theory & Panel data: OLS & Debt maturity & $\begin{array}{l}\text { Family ownership, } \\
\text { management and } \\
\text { reputation }\end{array}$ & Positive \\
\hline Elbannan (2017) & $\begin{array}{l}154 \text { listed } \\
\text { firms }\end{array}$ & Egypt & $\begin{array}{c}\text { Agency and } \\
\text { capital structure } \\
\text { theories }\end{array}$ & $\begin{array}{l}\text { Panel data: GMM } \\
\text { and OLS with } \\
\text { fixed effects }\end{array}$ & $\begin{array}{c}\text { Book and market } \\
\text { value of debt }\end{array}$ & Family ownership & Positive \\
\hline $\begin{array}{l}\text { González et al. } \\
\text { (2013) }\end{array}$ & $\begin{array}{l}523 \\
\text { listed and } \\
\text { unlisted } \\
\text { firms }\end{array}$ & Colombia & Agency theory & $\begin{array}{l}\text { Panel data: GLS } \\
\text { with random } \\
\text { effects }\end{array}$ & $\begin{array}{l}\text { Debt to total } \\
\text { assets ratio }\end{array}$ & $\begin{array}{l}\text { Family ownership } \\
\text { and management }\end{array}$ & $\begin{array}{l}\text { Vary } \\
\text { according to } \\
\text { firms age }\end{array}$ \\
\hline $\begin{array}{l}\text { Gottardo and } \\
\text { Moisello (2014) }\end{array}$ & $\begin{array}{c}\text { 3,006 } \\
\text { unlisted } \\
\text { firms }\end{array}$ & Italy & $\begin{array}{c}\text { Agency } \\
\text { theory and } \\
\text { socioemotional } \\
\text { wealth }\end{array}$ & $\begin{array}{l}\text { Panel data: OLS } \\
\text { with fixed effects }\end{array}$ & $\begin{array}{c}\text { Book value of } \\
\text { debt }\end{array}$ & $\begin{array}{l}\text { Family ownership } \\
\text { and management }\end{array}$ & Positive \\
\hline $\begin{array}{l}\text { Gottardo and } \\
\text { Moisello (2019) }\end{array}$ & $\begin{array}{l}2,986 \\
\text { listed and } \\
\text { unlisted } \\
\text { firms }\end{array}$ & Italy & $\begin{array}{c}\text { Socioemotional } \\
\text { wealth }\end{array}$ & Panel data: GLS & Book leverage & $\begin{array}{l}\text { Family ownership } \\
\text { and management }\end{array}$ & Positive \\
\hline Kayo (2018) & $\begin{array}{l}257 \text { listed } \\
\text { firms }\end{array}$ & Brazil & $\begin{array}{c}\text { Capital structure } \\
\text { theories }\end{array}$ & $\begin{array}{l}\text { Panel data: OLS } \\
\text { with fixed effects }\end{array}$ & $\begin{array}{c}\text { Market value of } \\
\text { debt }\end{array}$ & Family ownership & Positive \\
\hline $\begin{array}{l}\text { Keasey et al. } \\
(2015)\end{array}$ & $\begin{array}{l}1050 \text { listed } \\
\text { firms }\end{array}$ & $\begin{array}{c}16 \text { European } \\
\text { countries }\end{array}$ & $\begin{array}{c}\text { Life-cycle and } \\
\text { capital structure } \\
\text { theories }\end{array}$ & Panel data: GMM & $\begin{array}{l}\text { Book and market } \\
\text { value of debt }\end{array}$ & Family ownership & Positive \\
\hline $\begin{array}{l}\text { King and Santor } \\
(2008)\end{array}$ & $\begin{array}{l}613 \text { listed } \\
\text { firms }\end{array}$ & Canada & Agency theory & $\begin{array}{c}\text { Panel data: OLS } \\
\text { with random } \\
\text { effects }\end{array}$ & $\begin{array}{l}\text { Debt to total } \\
\text { assets ratio }\end{array}$ & Family ownership & Positive \\
\hline $\begin{array}{l}\text { Latrous and } \\
\text { Trabelsi (2012) }\end{array}$ & $\begin{array}{l}118 \text { listed } \\
\text { firms }\end{array}$ & France & Agency theory & $\begin{array}{c}\text { Panel data: OLS } \\
\text { with random } \\
\text { effects }\end{array}$ & $\begin{array}{l}\text { Debt to total } \\
\text { assets ratio }\end{array}$ & $\begin{array}{l}\text { Family ownership } \\
\text { and management }\end{array}$ & Negative \\
\hline $\begin{array}{l}\text { McConaughy et } \\
\text { al. (2001) }\end{array}$ & $\begin{array}{l}237 \text { listed } \\
\text { firms }\end{array}$ & USA & Agency theory & $\begin{array}{l}\text { Multivariate } \\
\text { matched pairs } \\
\text { analysis and } \\
\text { trend analysis }\end{array}$ & $\begin{array}{l}\text { Debt to total } \\
\text { assets ratio }\end{array}$ & Family management & Negative \\
\hline $\begin{array}{l}\text { Mishra and } \\
\text { McConaughy } \\
\text { (1999) }\end{array}$ & $\begin{array}{l}105 \text { listed } \\
\text { firms }\end{array}$ & USA & $\begin{array}{l}\text { Financial distress } \\
\text { (bankruptcy) }\end{array}$ & OLS & $\begin{array}{l}\text { Debt to total } \\
\text { assets ratio }\end{array}$ & Family management & Negative \\
\hline $\begin{array}{l}\text { Pindado et al. } \\
(2015)\end{array}$ & $\begin{array}{l}645 \text { listed } \\
\text { firms }\end{array}$ & $\begin{array}{l}\text { Eurozone } \\
\text { countries }\end{array}$ & $\begin{array}{c}\text { Pecking order } \\
\text { theory }\end{array}$ & Panel data: GMM & $\begin{array}{c}\text { Market value of } \\
\text { debt }\end{array}$ & $\begin{array}{l}\text { Family ownership } \\
\text { and management }\end{array}$ & Positive \\
\hline $\begin{array}{l}\text { Purag et al. } \\
\text { (2016) }\end{array}$ & $\begin{array}{l}195 \text { listed } \\
\text { firms }\end{array}$ & Malaysia & Agency theory & OLS & $\begin{array}{l}\text { Debt to total } \\
\text { assets ratio }\end{array}$ & Family management & Negative \\
\hline $\begin{array}{l}\text { Santos et al. } \\
(2014)\end{array}$ & $\begin{array}{l}694 \text { listed } \\
\text { firms }\end{array}$ & $\begin{array}{l}12 \text { Western } \\
\text { European } \\
\text { countries }\end{array}$ & $\begin{array}{c}\text { Capital structure } \\
\text { theories }\end{array}$ & Panel data: GMM & $\begin{array}{l}\text { Book and market } \\
\text { value of debt }\end{array}$ & Family ownership & Negative \\
\hline Schmid (2013) & $\begin{array}{l}\text { 4,007 firms } \\
\text { from }\end{array}$ & 21 countries & Agency theory & $\begin{array}{l}\text { Panel data: GMM } \\
\text { and OLS with } \\
\text { fixed effects }\end{array}$ & $\begin{array}{c}\text { Market value of } \\
\text { debt }\end{array}$ & $\begin{array}{l}\text { Family ownership } \\
\text { and management }\end{array}$ & Positive \\
\hline $\begin{array}{l}\text { Serrasqueiro et } \\
\text { al. }(2016)\end{array}$ & $\begin{array}{c}1,006 \\
\text { unlisted } \\
\text { firms }\end{array}$ & Portugal & $\begin{array}{l}\text { Pecking order } \\
\text { theory }\end{array}$ & Panel data: GMM & Debt variations & Family ownership & $\begin{array}{l}\text { Vary } \\
\text { according to } \\
\text { firm size and } \\
\text { age }\end{array}$ \\
\hline $\begin{array}{l}\text { Setia-Atmaja et } \\
\text { al. (2009) }\end{array}$ & $\begin{array}{l}316 \text { listed } \\
\text { firms }\end{array}$ & Australia & Agency theory & Panel data: OLS & $\begin{array}{l}\text { Debt to total } \\
\text { assets ratio }\end{array}$ & $\begin{array}{l}\text { Family ownership } \\
\text { and management }\end{array}$ & Positive \\
\hline $\begin{array}{l}\text { Setia-Atmaja } \\
(2010)\end{array}$ & $\begin{array}{l}316 \text { listed } \\
\text { firms }\end{array}$ & Australia & Agency theory & $\begin{array}{c}\text { Panel data: OLS } \\
\text { with random } \\
\text { effects }\end{array}$ & $\begin{array}{l}\text { Debt to total } \\
\text { assets ratio }\end{array}$ & $\begin{array}{l}\text { Family ownership } \\
\text { and management }\end{array}$ & Positive \\
\hline $\begin{array}{l}\text { Shyu and Lee } \\
\text { (2009) }\end{array}$ & $\begin{array}{l}611 \text { listed } \\
\text { firms }\end{array}$ & Taiwan & $\begin{array}{l}\text { Agency and } \\
\text { stewardship } \\
\text { theories }\end{array}$ & Panel data: GMM & Debt maturity & $\begin{array}{l}\text { Family ownership } \\
\text { and management }\end{array}$ & Negative \\
\hline $\begin{array}{l}\text { Thiele and } \\
\text { Wendt (2017) }\end{array}$ & $\begin{array}{c}691 \\
\text { unlisted } \\
\text { firms }\end{array}$ & Germany & $\begin{array}{c}\text { Capital structure } \\
\text { theories }\end{array}$ & $\begin{array}{c}\text { Panel data: OLS } \\
\text { with random } \\
\text { effects }\end{array}$ & $\begin{array}{c}\text { Debt to total } \\
\text { assets ratio }\end{array}$ & $\begin{array}{l}\text { Family ownership } \\
\text { and management }\end{array}$ & Positive \\
\hline
\end{tabular}


In the North American context, McConaughy et al. (2001) and Mishra and McConaughy (1999) found that U.S. FCFs use less debt than other firms. Anderson et al. (2003) supported this result. They found that industrial U.S. FCFs have fewer agency conflicts between equity holders and creditors and hence lower cost of outstanding debts. Baek et al. (2016) expressed conflicting views and reported that family ownership is positively associated with both the book and market value of debts. Additionally, King and Santor (2008) explored the influence of family ownership on the financial leverage of 6,013 Canadian firms, and their results showed that companies with family shares in excess of $20 \%$ hold a higher financial leverage based on a debt-to-total-assets ratio. An alternative view is that family involvement in business might not affect a firm's capital structure. Regarding this view, Anderson and Reeb (2003) found that U.S. industrial FCFs use the same level of debt as other companies.

Several studies also explored the capital structure of European firms. Acedo-Ramirez et al. (2017) investigated the factors that determine the capital structure decisions of Spanish firms and found that Spanish FCFs are more indebted compared to their nonfamily counterparts. Similarly, Díaz-Díaz et al. (2016) explored debt maturity structure in a sample of 4,365 private Spanish companies, and their findings showed that when family ownership exceeds $25 \%$ of the overall shares, firms have better access to long-term debt. Gottardo and Moisello $(2014,2019)$ examined the impact of family governance-related factors on the book value of debts of Italian firms. Insights generated from their studies showed that FCFs are more leveraged than nonfamily businesses, and the involvement of family members in management increases firms' debt levels. These findings align with those of Latrous and Trabelsi (2012) who reported that the appointment of a family member as a CEO in French listed firms leads to more debt utilization. Conversely, Amore et al. (2011) explored the influence of managerial successions on capital structure policies, and their findings revealed that the presence of a professional CEO (i.e., a nonfamily CEO) leads to a significant augmentation in debt levels of Italian FCFs.

Empirical findings from a bank-based financial system such as Germany also highlighted the in- fluence of family on capital structure decisions. Ampenberger et al. (2013) found that German FCFs hold less debt levels than their nonfamily counterparts; family influence is mostly driven by the participation of family members in management. These results are in line with those of prior studies conducted by Schmid (2013) who showed that FCFs in Germany are less leveraged than nonfamily businesses. However, Thiele and Wendt (2017) expressed conflicting views. They reported significant differences in the financing structure of German companies and showed that FCFs hold higher long-term and overall debt levels compared with nonfamily businesses.

As for firms operating in the Western European region, Santos et al. (2014) showed that the percentage of outstanding shares held by the family has a negative influence on the market value of debt. Conversely, Keasey et al. (2015) showed a positive impact of family ownership on debt levels, especially in young firms. These results demonstrated that founders and their families prefer to rely more on debt financing instead of diluting their control by issuing more equity shares. Similarly, Croci et al. (2011) found that Western European FCFs on average hold higher debt ratios than other firms; these results reveal that credit markets in Europe view investment decisions in FCFs as less risky than nonfamily businesses, and are more amenable to financing them with more debt. Additionally, Pindado et al. (2015) investigated whether family control can shape capital structure decisions and found a significant positive association between family ownership and the speed of adjustment toward target debt levels.

Finally, in attempts that can be considered limited, a few studies in the literature have investigated the association between family involvement in business and capital structure in emerging markets. Kayo (2018) explored the capital structure adjustment of 257 Brazilian listed firms and reported that FCFs tend to hold higher debt levels and have slower adjustment speeds than their nonfamily counterparts. Based on a sample of Australian listed firms, Setia-Atmaja et al. (2009) and Setia-Atmaja (2010) showed that firms controlled by a founding family appear to have a higher book value of debts compared to nonfamily companies. In line with previous findings, 
González et al. (2013) showed that direct or indirect family ownership levels are positively related to the usage of debt financing in Colombian firms. Similarly, Elbannan (2017) reported a significant positive relationship between the percentage of equity shares held by the family and debt levels in Egyptian listed firms. However, a conflicting view reported that family control might lead to less demand for debt financing. In this regard, Shyu and Lee (2009) showed that excess control rights are negatively associated with short-term debt levels in Taiwanese FCFs.

Based on the above discussion, we found two contradictory perspectives in the financial literature. The first view contends that FCFs are less leveraged than their nonfamily counterparts (Gama \& Galvão, 2012). The negative impact of family involvement on debt levels has confirmed the findings of previous studies (Ampenberger et al., 2013; Mishra \& McConaughy, 1999; McConaughy et al., 2001; Santos et al., 2014). According to this view, family capital collected in a single enterprise results in an under-diversified portfolio, hence, the risk of bankruptcy and the prospect of financial distress will force the family business to rely less on debt financing (Santos et al., 2014). However, the alternative view argues that FCFs are more indebted than nonfamily businesses (e.g., Croci et al., 2011; Díaz-Díaz et al., 2016; Kayo, 2018; Setia-Atmaja, 2010; Thiele \& Wendt, 2017). In line with this argument, the literature has reported that the presence of family members in top management and their ownership stake leads to an increase in the firm's overall debt levels (Baek et al., 2016; Elbannan, 2017; Gottardo \& Moisello, 2019; King \& Santor, 2008).

To find a solution to this dilemma, Schmid (2013) pointed out that this ideological conflict is due to variations in creditor monitoring levels. Therefore, in the presence of high creditor monitoring levels, FCFs show a propensity to avoid debt financing, and the opposite holds true when creditors have less probability of exerting their influence (Schmid, 2013). In sum, insights generated from prior studies are mixed because of differences in the definition of a family firm, sample characteristics, legal systems, time horizons, countries/regions under review, and the inability to identify the differential effects of family ownership, management, and control (Baek et al., 2016).

\section{DISCUSSION}

In the financial literature, researchers use two primary theories to explain the interrelationships between different stakeholders in a corporation: agency theory and stewardship theory. From the perspective of agency theory, the separation between ownership and control creates a situation in which agents (managers) seek to satisfy their own interests on behalf of firm owners, generating agency costs that can be diluted by monitoring agents' behavior through corporate governance mechanisms (Jensen \& Meckling, 1976). Thus, it can be predicted that FCFs have lower agency costs compared with their nonfamily counterparts and hence more cost minimization and better performance.

Conversely, stewardship theory posits that leaders and executives are stewards with a substantial willingness to serve the company; hence, they will be in alignment with the owners' interests (Madison et al., 2015). Therefore, stewardship theory predicts that family ownership and the participation of founders and their family members in firm management and control shall reduce agency costs because of the ability of family leaders to act as altruistic stewards of family wealth. In turn, firm financial performance will increase (Cai et al., 2012; Graves \& Shan, 2013).

Empirical studies have generally reported that FCFs outperform nonfamily businesses (e.g., Anderson \& Reeb, 2003; Gama \& Rodrigues, 2013; Halili et al., 2015; McConaughy et al., 2001). The opposing view in the literature argues that firms managed by the founding family attain low performance rates because of the inability of family influence to outweigh agency costs. Other reasons for such a negative impact are a lack of family agent professional competencies, an orientation toward nonfinancial goals, and risk aversion behavior by family managers (Bauweraerts \& Colot, 2016; Klein et al., 2005; McConaughy et al., 2001; Naldi et al., 2007; Sciascia \& Mazzola, 2008).

At the same time, firms can attain financial flexibility through capital structure decisions, corporate cash holdings, and payout policies. Firms with lower debt capacity, large cash balances, and increased payouts have excess financial flexibility 
(Arslan-Ayaydin et al., 2014; Bancel \& Mitto, 2011; Denis, 2011; Lie, 2005; Marchica \& Mura, 2010). As for capital structure decisions, prior studies found that FCFs utilize more debt than nonfamily businesses (e.g., Croci et al., 2011; King \& Santor, 2008; Setia-Atmaja, 2010). This positive impact of family involvement on debt levels might be explained by the implications of the pecking order theory of capital structure (Oktavina et al., 2018). According to this theory, managers prefer internal sources of finance first, and then they will move toward debt financing and issuing new equity shares as the last source of finance. In line with the prior view, Pindado et al. (2015) argued that powerful agency conflicts in family businesses between owners (i.e., the family) and creditors will lead to evident pecking order behavior. Thus, agents (family managers) in FCFs prefer to utilize more debts instead of diluting their control by issuing more equity shares (Keasey et al., 2015).

However, conflicting views have argued that FCFs hold less debt levels than other firms, and these views are in line with the implications of trade-off theory (Ampenberger et al., 2013; McConaughy et al., 2001; Santos et al., 2014; Schmid, 2013). According to the trade-off theory of capital structure, companies seek to possess the debt level at which balance is achieved between the costs of potential financial distress and the tax advantages of extra debts (Myers, 2001). As for FCFs, executives are expected to pay more attention to the risk of bankruptcy and the prospect of financial distress; hence, they will be less motivated to optimize more debts (Santos et al., 2014). Additionally, FCFs have fewer agency conflicts between equity holders (i.e., family owners) and debt holders and hence have a lower cost of debt financing (Anderson et al., 2003).

Based on the above discussion, debt as an alter- native source of finance might be affected positively and/or negatively by family ownership and the participation of founders and their family members in firm management and control activities. The nonlinear association between family involvement in business and debt levels might explain such a contradictory effect. In this context, Schulze et al. (2003) argued that the association between ownership dispersion of managers and debt levels in U.S. FCFs follows a U-shaped relationship. These findings indicate that FCFs are most exposed to conflict and least reticent about bearing added risk. These findings are quite close to the implications of the socioemotional wealth (SEW) approach.

As developed on the implications of behavioral agency theory, Gomez-Mejia et al. (2007) introduced the concept of SEW. It refers to the nonfinancial aspects of a firm that meet the family's affective needs; these aspects include family identity, immortalization of the family dynasty, and family desire to exercise authority. Thus, family businesses are committed to preserving their SEW (Berrone et al., 2012). According to the implications of the SEW model, the behavior of family firms can be categorized as risk-averse or risk-willing. Risk-averse FCFs are less willing to accept projects with high performance variances that might further increase the firm's probability of failure. However, FCFs might accept the risk of greater performance hazards to protect their SEW (Gomez-Mejia et al., 2007; Gomez-Mejia et al., 2011). Therefore, the use of debt as an alternative source of finance in family firms is shaped by the procedures that the founding family uses to protect its SEW. Hence, it can be argued that both the trade-off theory and pecking order theory of capital structure fail to explain the variation in the utilization of debts between FCFs and nonfamily businesses (Gottardo \& Moisello, 2019).

\section{CONCLUSION}

The main purpose of this study was to review the literature on how family involvement in business through ownership, management, and control affects capital structure decisions. Based on the review, we concluded that FCFs on average hold higher debt levels compared with nonfamily businesses. Additionally, the literature review found that firm debt levels are positively affected by the degree of family ownership and that the participation of family members in top management leads to an increase in firm debt levels. 
The literature offers different causes for the positive influence of family involvement in business on debt levels. One proposed cause is that FCFs have fewer agency conflicts between equity holders (i.e., family owners) and debt holders and hence a lower cost of debt financing. Other studies have argued that credit markets view investments in family businesses as less risky, and they are more amenable to financing such businesses with more debts. Moreover, founders and their families prefer to satisfy their firms' financial needs through debt instead of diluting their control by issuing more equity shares, use leverage to reflect the quality of their companies' investments, and can utilize capital structure decisions as a mechanism by which they can optimize their dominance over the firm.

The capital structure literature also revealed an inability to rely on agency, stewardship, and capital structure theories alone in interpreting the capital structure decisions of FCFs. Therefore, there is an urgent need to adopt the SEW approach because of its deeper understanding of the circumstances of the nonfinancial aspects of family businesses and how these might affect the association between family involvement in business and potentially affect firm performance and key financial policies.

The current study provides many insights for further research, but it also has some limitations. First, this study focused on reviewing the capital structure literature on large FCFs only. Expanding the study to include small- and medium-sized firms (SMEs) could better explain how family involvement in SMEs can affect capital structure decisions. Second, the current study was limited to a review of quantitative-based studies only; future studies can review studies that are qualitative based. Finally, as previously discussed, there is a paucity of studies that have utilized the SEW approach in investigating the financial behavior of FCFs; future studies consider adopting this approach.

\section{REFERENCES}

1. Acedo-Ramirez, M. A., Calvo, J. C. A., \& Navarrete-Martinez, E. (2017). Determinants of capital structure: family businesses versus non-family firms. Czech Journal of Economics and Finance, 67(2), 80-103. Retrieved from https:// ideas.repec.org/a/fau/fauart/ v67y2017i2p80-103.html

2. Amore, M. D., Minichilli, A., \& Corbetta, G. (2011). How do managerial successions shape corporate financial policies in family firms? Journal of Corporate Finance, 17(4), 1016-1027. https://doi.org/10.1016/j.jcorpfin.2011.05.002

3. Ampenberger, M., Schmid, T., Achleitner, A.-K., \& Kaserer, C. (2013). Capital structure decisions in family firms: empirical evidence from a bank-based economy. Review of Managerial Science, 7(3), 247-275. https://doi. org/10.1007/s11846-011-0077-2

4. Anderson, R. C., Mansi, S. A., \& Reeb, D. M. (2003). Founding family ownership and the agency cost of debt. Journal of Finan- cial Economics, 68(2), 263-285. https://doi.org/10.1016/S0304405X(03)00067-9

5. Anderson, R. C., \& Reeb, D. M. (2003). Founding-family ownership, corporate diversification, and firm leverage. The Journal of Law and Economics, 46(2), 653-684. https://doi.org/10.1086/377115

6. Arslan-Ayaydin, O., Florackis, C., \& Ozkan, A. (2014). Financial flexibility, corporate investment and performance: evidence from financial crises. Review of Quantitative Finance and Accounting, 42(2), 211-250. https://doi. org/10.1007/s11156-012-0340-x

7. Bancel, F., \& Mittoo, U. R. (2011). Financial flexibility and the impact of the global financial crisis: Evidence from France. International Journal of Managerial Finance, 7(2), 179-216. http://dx.doi. org/10.1108/17439131111122157

8. Baek, H. Y., Cho, D. D., \& Fazio, P. L. (2016). Family ownership, control and corporate capital structure: An examination of small capitalization public firms. Journal of Family Business Management, 6(2), 169-185. https://doi. org/10.1108/JFBM-02-2015-0006

9. Bauweraerts, J., \& Colot, O. (2016). Performance, corporate governance and socioemotional wealth in Belgian family firms. International Advances in Economic Research, 22(2), 243-244. https://doi. org/10.1007/s11294-016-9580-1

10. Berrone, P., Cruz, C., \& GomezMejia, L. R. (2012). Socioemotional wealth in family firms: theoretical dimensions, assessment approaches, and agenda for future research. Family Business Review, 25(3), 258-279. https://doi. org/10.1177/0894486511435355

11. Cai, D., Luo, J. H., \& Wan, D. F. (2012). Family CEOs: Do they benefit firm performance in China? Asia Pacific Journal of Management, 29(4), 923-947. https://doi. org/10.1007/s10490-012-9318-4

12. Croci, E., Doukas, J. A., \& Gonenc, H. (2011). Family control and financing decisions. European 
Financial Management, 17(5), 860-897. https://doi.org/10.1111/ j.1468-036X.2011.00631.x

13. Che, L., \& Langli, J. C. (2015). Governance structure and firm performance in private family firms. Journal of Business Finance and Accounting, 42(9-10), 12161250. https://doi.org/10.1111/ jbfa.12170

14. Denis, D. J. (2011). Financial flexibility and corporate liquidity. Jour nal of Corporate Finance, 17(3), 667-674. https://doi.org/10.1016/j. jcorpfin.2011.03.006

15. Díaz-Díaz, N. L., García-Teruel, P. J., \& Martínez-Solano, P. (2016). Debt maturity structure in private firms: Does the family control matter? Journal of Corporate Finance, 37, 393-411. https://doi. org/10.1016/j.jcorpfin.2016.01.016

16. ElBannan, M. A. (2017). Stock market liquidity, family ownership, and capital structure choices in an emerging country. Emerging Markets Review, 33, 201-231. https://doi.org/10.1016/j.ememar.2017.11.001

17. Global Family Business Center of Excellence (2014). Family Business Yearbook 2014. London, UK: Ernst and Young Global Limited. Retrieved from https://familybusiness.ey-vx.com/insights/familybusiness-yearbook-2014.aspx

18. Gama, A. P. M., \& Galvão, J. M. M. (2012). Performance, valuation and capital structure: survey of family firms. Corporate Governance: The international journal of business in society, 12(2), 199-214. https://doi. org/10.1108/14720701211214089

19. Gama, A. P. M., \& Rodrigues, C. (2013). The governance-performance relations in publicly listed family controlled firms: an empirical analysis. Corporate Governance: The international journal of business in society, 13(4), 439-456. https://doi.org/10.1108/ CG-04-2011-0031

20. Graves, C., \& Shan, Y. G. (2013). An empirical analysis of the effect of internationalization on the performance of unlisted family and nonfamily firms in Australia. Family Business Review, 27(2), 142-160. https://doi. org/10.1177/0894486513491588

21. Gomez-Mejia, L. R., Cruz, C., Berrone, P., \& De Castro, J. (2011). The bind that ties: socioemotional wealth preservation in family firms. The Academy of Management Annals, 5(1), 653-707. https://doi.org/10.1080/19416520. 2011.593320

22. Gomez-Mejia, L. R., Haynes, K. T., Núñez-Nickel, M., Jacobson, K. J. L., \& Moyano-Fuentes, J. (2007). Socioemotional wealth and business risks in family-controlled firms: evidence from Spanish olive oil mills. Administrative Science Quarterly, 52(1), 106-137. https:// doi.org/10.2189/asqu.52.1.106

23. González, M., Guzmán, A., Pombo, C., \& Trujillo, M.-A. (2013). Family firms and debt: Risk aversion versus risk of losing control. Journal of Business Research, 66(11), 2308-2320. https://doi. org/10.1016/j.jbusres.2012.03.014

24. Gottardo, P., \& Moisello, A. M. (2014). The capital structure choices of family firms: Evidence from Italian medium-large unlisted firms. Managerial Finance, 40(3), 254-275. https://doi. org/10.1108/MF-03-2013-0065

25. Gottardo, P., \& Moisello, A. M (2019). Family control and capital structure choices. In P. Gottardo \& A. Moisello (Eds.), Capital Structure, Earnings Management, and Risk of Financial Distress: A Comparative Analysis of Family and Non-family Firms (pp. 13-40). Cham: Springer International Publishing. https://doi. org/10.1007/978-3-030-00344-9_2

26. Halili, E., Saleh, A. S., \& Zeitun, R. (2015). Governance and long-term operating performance of family and non-family firms in Australia. Studies in Economics and Finance, 32(4), 398-421. https://doi.org/10.1108/SEF-022014-0034

27. Jensen, M., \& Meckling, W. (1976) Theory of the firm: managerial behavior, agency costs and ownership structure. Journal of Financial Economics, 3(4), 305360. https://doi.org/10.1016/0304405X(76)90026-X
28. Kayo, E. K., Brunaldi, E. O., \& Aldrighi, D. M. (2018). Capital structure adjustment in brazilian family firms. Revista de Administração Contemporânea, 22(1), 92-114. http://dx.doi.org/10.1590/19827849rac2018170004

29. Keasey, K., Martinez, B., \& Pindado, J. (2015). Young family firms: Financing decisions and the willingness to dilute control. Journal of Corporate Finance, 34 47-63. https://doi.org/10.1016/j. jcorpfin.2015.07.014

30. King, M. R., \& Santor, E. (2008). Family values: ownership structure, performance and capital structure of Canadian firms. Journal of Banking and Finance, 32(11), 2423-2432. https://doi.org/10.1016/j.jbankfin.2008.02.002

31. Klein, P., Shapiro, D., \& Young, J. (2005). Corporate governance, family ownership and firm value: the Canadian evidence. Corporate Governance: An International Review, 13(6), 769-784. https://doi.org/10.1111/j.14678683.2005.00469.x

32. Kusnadi, Y., \& Wei, K. C. J. (2011). The determinants of corporate cash management policies: Evidence from around the world. Journal of Corporate Finance, 17(3), 725-740. https://doi. org/10.1016/j.jcorpfin.2010.12.002

33. Lie, E. (2005). Financial flexibility, performance, and the corporate payout choice. The Journal of Business, 78(6), 2179-2202. https://doi. org/10.1086/497043

34. Latrous, I., \& Trabelsi, S. (2012). Do family firms use more or less debt? International Journal of Corporate Governance, 3(2-4), 182-209. https://doi.org/10.1504/ IJCG.2012.051861

35. Mishra, C. S., \& Mcconaughy, D. L. (1999). Founding family control and capital structure: the risk of loss of control and the aversion to debt. Entrepreneurship Theory and Practice, 23(4), 53-64. https://doi. org/10.1177/104225879902300404

36. Mishra, C. S., Randoy, T., \& Jenssen, J. I. (2001). The effect of founding family influence on firm 
value and corporate governance. Journal of International Financial Management and Account ing, 12(3), 235-259. https://doi org/10.1111/1467-646X.00073

37. McConaughy, D. L., Matthews, C. H., \& Fialko, A. S. (2001). Founding family controlled firms: performance, risk, and value. Journal of Small Business Management, 39(1), 31-49. https://doi org/10.1111/0447-2778.00004

38. Madison, K., Holt, D. T., Kellermanns, F. W., \& Ranft, A. L. (2015). Viewing family firm behavior and governance through the lens of agency and stewardship theories. Family Business Review, 29(1), 65-93. https://doi. org/10.1177/0894486515594292

39. Marchica, M.-T., \& Mura, R. (2010). Financial flexibility, investment ability, and firm value: evidence from firms with spare debt capacity. Financial Management, 39(4), 1339-1365. https://doi.org/10.1111/j.1755053X.2010.01115.X

40. Myers, S. C. (2001). Capital structure. The Journal of Economic Perspectives, 15(2), 81-102. Retrieved from http://ecsocman. hse.ru/data/863/126/1231/myers_-_cs_2001.pdf

41. Naldi, L., Nordqvist, M., Sjöberg, K., \& Wiklund, J. (2007). Entrepreneurial orientation, risk taking, and performance in family firms. Family Business Review, 20(1), 3347. https://doi.org/10.1111/j.17416248.2007.00082.x

42. Oktavina, M., Manalu, S., \& Yuniarti, S. (2018). Pecking order and trade-off theory in capital structure analysis of family firms in Indonesia. Jurnal Keuangan dan Perbankan, 22(1), 73-82. https:// doi.org/10.26905/jkdp.v22i1.1793

43. Pindado, J., Requejo, I., \& de la Torre, C. (2015). Does family control shape corporate capital structure? An empirical analysis of Eurozone firms. Journal of Business Finance and Accounting, 42(7-8), 965-1006. https://doi. org/10.1111/jbfa.12124

44. Purag, M. B., Abdullah, A., \& Bujang, I. (2016). Corporate gov- ernance and capital structure of Malaysian family-owned companies. Journal of Business and Retail Management Research, 11(1), 18-30. Retrieved from https://uitm. pure.elsevier.com/en/publications/corporate-governance-andcapital-structure-of-malaysianfamily-ow

45. Setia-Atmaja, L. (2010). Dividend and debt policies of family controlled firms: The impact of board independence. International Journal of Managerial Finance, 6(2), 128-142. https://doi. org/10.1108/17439131011032059

46. Setia-Atmaja, L., Tanewski, G. A., \& Skully, M. (2009). The role of dividends, debt and board structure in the governance of family controlled firms. Journal of Business Finance and Accounting, 36(7-8), 863-898. https://doi.org/10.1111/j.14685957.2009.02151.x

47. Santos, M. S., Moreira, A. C., \& Vieira, E. S. (2014). Ownership concentration, contestability, family firms, and capital structure. Journal of Management and Governance, 18(4), 1063-1107. https://doi.org/10.1007/s10997013-9272-7

48. Sciascia, S., \& Mazzola, P. (2008). Family involvement in ownership and management: Exploring nonlinear effects on performance. Family Business Review, 21(4), 331-345. https://doi.org/10.1177/0 8944865080210040105

49. Schmid, T. (2013). Control considerations, creditor monitoring, and the capital structure of family firms. Journal of Banking and Finance, 37(2), 257-272. http:// dx.doi.org/10.1016/j.jbankfin.2012.08.026

50. Schulze, W. S., Lubatkin, M. H., \& Dino, R. N. (2003). Exploring the agency consequences of ownership dispersion among the directors of private family firms. Academy of Management Journal, 46(2), 179-194. https://doi. org/10.5465/30040613

51. Shyu, Y.-W., \& Lee, C. I. (2009) Excess control rights and debt maturity structure in familycontrolled firms. Corporate
Governance: An International Review, 17(5), 611-628. https:// doi.org/10.1111/j.14678683.2009.00755.x

52. Serrasqueiro, Z., Nunes, P. M., \& da Silva, J. V. (2016). The influence of age and size on familyowned firms' financing decisions: empirical evidence using panel data. Long Range Planning, 49(6), 723-745. https://doi.org/10.1016/j. lrp.2015.12.012

53. Thiele, F. K., \& Wendt, M. (2017). Family firm identity and capital structure decisions. Journal of Family Business Management, 7(2), 221-239. https://doi.org/10.1108/ JFBM-05-2017-0012

54. Villalonga, B., Amit, R., Trujillo, M.-A., \& Guzmán, A. (2015). Governance of family firms. Annual Review of Financial Economics, 7(1), 635-654. https:// doi.org/10.1146/annurev-financial-110613-034357

55. Vandemaele, S., \& Vancauteren, M. (2015). Nonfinancial goals, governance, and dividend payout in private family firms. Journal of Small Business Management, 53(1), 166-182. https://doi.org/10.1111/ jsbm. 12063 